\title{
Language Appropriations, Ideologies and Identities in Bilingual Schools in Castilla-La Mancha (Spain)
}

\author{
Alicia Fernández Barrera \\ University of Castilla-La Mancha (UCLM), Spain
}

Article received 10 September 2016, accepted 4 October 2016, final version 7 February 2017

DOI: http://dx.doi.org/10.5565/rev/jt13.731

\begin{abstract}
This article addresses language ideologies and identities through the appropriations of the English language in two prestigious secondary bilingual schools in La Mancha City (pseudonym), as part of a team-based linguistic ethnography carried out in the region of Castilla-La Mancha (Spain). Since the exponential increase in different types of bilingual programmes (SpanishEnglish), language ideologies circulating among the local 'imagined' bilingual communities as well as bilingual identities of school stakeholders have been transformed and (re)shaped within the era of 'bilingualism fever'. By drawing on linguistic and ethnographic empirical insights on CLIL classroom practices and interviews, this article explores how bilingual identities are co-constructed in relation to language policies, language ideologies and appropriations of English within the institutional spaces as a marker of distinction, elitism and prestige in the local/global market.
\end{abstract}

Key words: appropriations, bilingualism, ideologies, identities, linguistic ethnography

\section{Résumé}

Cet article traite des idéologies linguistiques et des identités à travers les appropriations de la langue anglaise dans deux prestigieux lycées bilingues à $\mathrm{La}$ Mancha City (pseudonyme), dans le cadre d'une ethnographie linguistique menée par une équipe dans la région de Castilla-La Mancha (Espagne). Depuis l'augmentation exponentielle des différents types du programme bilingue (espagnol-anglais), des idéologies linguistiques circulant parmi les communautés bilingues locales « imaginées » ainsi que les identités bilingues des parties prenantes de l'école ont été transformées et (re)façonnées dans l'ère de la " fièvre de bilinguisme ». En s'appuyant sur les connaissances empiriques linguistiques et ethnographiques sur les pratiques CLIL en classe et sur les entretiens, cet article explore comment les identités bilingues sont coconstruites en relation avec les politiques et les idéologies linguistiques et les appropriations de l'anglais dans les espaces institutionnels en tant que marque de distinction, d'élitisme et de prestige dans le marché local et global.

Mots clés: appropriations, bilinguisme, ethnographie linguistique, identités, idéologies

\section{Resumen}

Este artículo aborda las ideologías lingüísticas e identidades a través de las apropiaciones de la lengua inglesa en dos prestigiosos centros de secundaria bilingües en La Mancha City (pseudónimo), que forman parte de una etnografía lingüística en equipo llevada a cabo en la región de Castilla-La Mancha (España). Desde el aumento exponencial de diferentes tipos de programas bilingües (español-inglés), las ideologías lingüísticas que circulan entre las 
comunidades 'imaginadas' como bilingües a nivel local, así como las identidades bilingües de los agentes sociales implicados en los centros, se han transformado en la era de "la fiebre del bilingüismo". Tomando la etnografía lingüística como acercamiento metodológico empírico para analizar las prácticas de CLIL en el aula y las entrevistas, este artículo explora cómo se coconstruyen las identidades bilingües en relación con las políticas lingüísticas, las ideologías y las apropiaciones del inglés en los espacios institucionales como marca de distinción, elitismo y prestigio en el mercado local y global.

Key words: apropiaciones, bilingüismo, etnografía lingüística, identidades, ideologías

\section{Introduction}

Over the last two decades, bilingual education in the central autonomous community of Castilla-La Mancha has been transformed by the effects of increasing globalisation and the dominance of English as a lingua franca (ELF) (Seidlhofer, 2005). There have been significant transformations not only at the institutional level but also in terms of ideologies and identities. Having Castilian as the official language, central Spain has traditionally held a monolingual view of the sociolinguistic regional panorama. However, through the new linguistic landscape a more plurilingual perspective has emerged. Social demand for foreign language competence, mainly English, has increased. In turn, language policy makers have prioritised foreign language learning through mainstream education.

Consequently, an exponential increase in bilingual education programmes was initiated as part of a signed agreement between the Spanish Ministry of Education, Culture and Sports (MECD) and the British Council (1996), thus implementing the 'Bilingual and Bicultural Project' through a Content and Language Integrated Learning approach (CLIL). CLIL is defined as a dual-focused educational approach emerging in the early nineties which involves an additional language as a medium of instruction for learning and teaching of both content and language (Coyle, Hood, \& Marsh, 2010).

In a region which has traditionally felt ashamed of its citizens' poor English skills (compared to other European countries), the schools of Castilla-La Mancha have successfully reimagined themselves as bilingual communities. Here, the term 'bilingual communities' refers to those Spanish speakers involved in the process of teaching/learning English as part of one of the Linguistic Programmes implemented in most schools of the region. The desire of these school communities is to be able to function equally well in both English and Spanish, transforming dominant self-perceptions and ideas of what it means to be bilingual.

Despite the efforts made in order not to be left behind the rest of the European 
members in terms of bilingual education and English proficiency, the common feeling of inferiority remains. This is illustrated by the following extract from an interview conducted with Julia, the English language teacher in San Marcos' School, one of the focal educational sites in this article:

\section{Extract 1. San Marcos'. Interview with Julia. ${ }^{1}$}

From a comparative point of view with the rest of Europe [...] we are shameful. The English are, for example, worse without doubt. But we are shameful. And it is weird if you go to the Netherlands or Denmark, or other countries, the normal thing is that they have their language, maybe because they think they are a corpuscle. I think all people there are bilingual. I think governments here in Spain expect us to be compared with that. What I don't know is if we will because maybe the motivations are different, the historical background is different, or many other stories, but I think that the fact striving for this is because they say 'damn it, if the Dutch can do it, why can't I?'

An English teacher for many years, Julia's scepticism about becoming bilingual brings to the fore ideological and identity issues which have emerged from the rapid implementation of socalled 'Linguistic Programmes' currently practised in most primary and secondary schools in Castilla-La Mancha.

In this article, I consider these schools in Castilla-La Mancha to be "imagined" bilingual communities (Anderson, 1991; Pavlenko \& Norton, 2007), in the process of reconfiguring their institutional identities. For this purpose, this article discusses what being bilingual actually means, in two school communities of Castilla-La Mancha, by addressing the following questions:

1) How is English appropriated in these institutional spaces?

2) What language ideologies circulate among stakeholders' discourse and how are they socially constructed, reproduced, transformed or contested in daily classroom practice?

3) How do language ideologies shape and how are they shaped by participants' and schools' identity as members of an "imagined" bilingual community?

Drawing on Heller's social perspective, the purpose of this article is to discuss different conceptions, beliefs and values concerning bilingualism as a rather "materialist approach which privileges language as social practice, speakers as social actors and boundaries as products of social action" (2007, p. 1). This way, bilingualism is understood as ideology and practice; it is therefore through situated social practices that this paper attempts to describe the extent to which language policies influence ideologies and identities, and how these two dimensions are interactionally co-constructed from a sociolinguistic ethnographic approach. This may be defined as a qualitative approach based on epistemological and ontological ways 
of understanding the social world through a close analysis of communicative situated practices (Heller, 2006; Copland \& Creese, 2015).

Section two of this paper gives an overview of the language policies implemented in Castilla-La Mancha as central to understanding ideological and identity shifts, while section three focuses on the methodology, and briefly describes the two schools under study. Section four, explores the commodification of English, elitism and bilingual identities. The last section comprises a critical reflection on the most relevant issues discussed in this article: the language ideologies emerging in discourse and interaction regarding the concept of bilingualism, the appropriations of English and legitimisation of certain language practices as well as social categorisation processes in these bilingual schools.

\section{Language policies in La Mancha: ideological and identity shifts}

In Castilla-La Mancha, bilingualism and bilingual education have been two politically and socially controversial issues since the initial implementation of the so-called 'bilingual programmes' (BPs, hereafter) in both primary and secondary schools. In 1996, the first BPs implemented in La Mancha region ('MECD/ British Council Agreement') had two main goals: to increase the students' level of English, and to offer students the possibility of attending an official bilingual and bicultural curriculum in state schools following CLIL parameters (de Zarobe \& Lasagabaster, 2010).

These BPs under European language-in-education policies (LiEP) have undergone several nomenclatures in the last decade. In 2014, they became Programas Lingüisticos ('Linguistic Programmes') under the provisions of the regional Plan de Plurilingüismo ('Plan of Plurilingualism'). These Linguistic Programmes made it possible for any school, state, private or state-subsidised, to opt into this type of bilingual education. One of the main goals of the Plan of Plurilingualism is to make Castilla-La Mancha bilingual by 2018 (see: El Diario, 2014). As the number of schools implementing one of these Linguistic Programmes has increased dramatically since 2005 , it seems that language policy makers in this region are on the way to realising the dream of becoming Spanish-English bilingual.

Every school is expected to implement one of the Linguistic Programmes promoted by the Plan of Plurilingualism. Students can choose the bilingual curriculum, thus attending one, two or three subjects taught in English alongside the corresponding English language subject. Programmes can be adapted by schools according to the availability of teachers qualified to teach content subjects in English. Teachers involved in the programme are required to reach a 
minimum B2 level (intermediate) of English according to the Common European Framework of Reference for Language Learning (CEFR, 2001). Despite having their own bilingual education programmes, the two state-subsidised religious schools selected here as objects of study have opted into the regional Linguistic Programmes.

Spaniards' lack of communicative skills in a second language has become an outstanding feature of their traditional 'monolingual' identity. This was strictly reinforced by nationalist ideologies during the Franco dictatorship (1939-1975), and for many decades the Spanish education system was constrained to a rather draconian monolingual model. This placed Spain behind those European countries which had quickly recognise the importance of English language competence in an increasingly globalised world; hence the urgent implementation of new LiEP.

In today's plurilingual and multicultural scenario, English has become the global language for communication: an instrument or a product of New Capitalism, for which "knowledges are produced, circulated and consumed" (Fairclough, 2002: 164). In this sense, English carries a symbolic capital that enables individuals to gain access to the global market (Bourdieu, 1985). However, LiEP have also been attempting in the last decade to achieve a more varied sociolinguistic reality not only in terms of multilingualism, understood as the varieties of languages in the whole European territory, but also plurilingualism, reflecting the languages individuals may use in a specific geographical area. LiEP in Europe aim at achieving social cohesion and integration of European nations, including minority languages and identities. In this sense, both the Council of Europe and the European Commission promote linguistic diversity to "enable citizens to communicate in two languages other than their mother tongue" (Barcelona European Council, 2002). The adoption of CLIL programmes was one way of achieving this. The explosion of interest in CLIL spread across the European Member States, putting a special emphasis on early language learning but at the same time challenging existing effective pedagogical practices.

LiEPs in Castilla La-Mancha are key to understanding more clearly the significant ideological shift from considering 'being monolingual' as shameful towards a feeling of pride attached to 'becoming bilingual'. Languages have gained value both in the political and social arena, and have transformed the school communities. The symbolic capital attributed to certain languages by social actors, is tightly linked with wider ideologies embedded in political and economic processes (Bourdieu, 1985). One dominant linguistic ideology which circulates among education stakeholders' discourse is that "students following this 
programme are expected to be able to manage themselves in different cultures and to be better prepared to face the $21^{\text {st }}$ century demands in a more and more competitive and multilingual Europe" (MECD, 2016).

Language learning in Spain has always focused on a traditional method which lacks emphasis on communicative skills (Gálvez, 2000); the implementation of bilingual programmes was therefore intended to shift language pedagogy towards a more communicative approach to linguistic competence. These first bilingual programmes combined Spanish and English, while some trilingual programmes included French or German. Since then, bilingual schools in Castilla-La Mancha have acquired a prestigious status. The programmes have been provided with the support of a native English assistant for every state school so as to promote this type of bilingual education, and thus encouraging all schools to implement the regional language policies. In this sense, these native language assistants represent the Chomskyan "ideal speaker" concept (1965), as they are regarded as authentic speakers of English, and thus considered key to the process of implementation of such programmes. In subsidised schools, these native English assistants are hired by the school itself.

Bilingual education in this region thus carries an added symbolic value of "pride and profit" (Duchêne \& Heller 2012, pp. 4-7), since it is within institutional sites that language is utilised as a source of pride and prestige to compete in the market place. Schools' linguistic resources are used to promote a top-quality education that will open doors to students when accessing higher education and the job market. In this way, the English language per se is commodified as embedding power and capital (Park, 2011) against the backdrop of globalisation processes related to transnational mobility and neoliberal forces.

Whereas language policy makers are adopting the English language as a source of pride, prestige and profit in the local and global market, institutional sites are in turn appropriating English (Lin, Wang, Akamatsu, \& Riazi, 2002) in their curricular activities and linguistic practices to construct their own identity as bilingual school communities. School stakeholders as local agents socially construct their "bilingual selves" (Pavlenko, 2006) through the circulation and transformation of ideologies related to the concept of bilingualism and bilingual programmes.

In the case of institutional spaces in Castilla-La Mancha, appropriating the English language into the daily functioning and communicative practices serves two functions. It is a marketing strategy to attract students, that is, bilingual education as a service and foreign 
language learning as a product (see the customer metaphor by Holborow, 2007); it is also a way to co-construct their identity within an "imagined" bilingual community (Anderson, 1991; Pavlenko \& Norton, 2007). No rigid measures are taken at the national/regional level in designing the bilingual curriculum; this allows schools to adjust LiEP on their own terms. Schools' own management of their bilingual programmes thus implies a sense of ownership/membership (Pavlenko \& Norton, 2007) of a particular social group, that of a specific school community whose bilingual programme stands out as distinctive and prestigious.

\section{Methodology: data collection and description of sites}

Linguistic ethnographies provide analytical tools and empirical methods to better understand meaning-making in situated social practices (Copland \& Creese, 2015). In this article, I adopt a linguistic ethnographic perspective in order to explore the relationship between language ideologies and identity construction through situated appropriations of the English language in two educational settings which have implemented the Linguistic Programmes.

\section{Data collection}

Data collection in two institutional sites in La Mancha City involved long-term participant observation (2014-16), fine-grained field notes, school artefacts (e.g. school brochures, pictures from institutional spaces and teaching material) and institutional documents of the LiEP implemented in Castilla-La Mancha. I also audio-recorded the following: 1) classroom interactions in content subjects taught in English; 2) semi-structured interviews with teachers, students, bilingual programme coordinators, educational inspectors and language policy makers; and 3) focus group discussions with students in the BP. These data were collected with the aim of identifying the language ideologies circulating amongst participants, and underpinning the curricula developed by the schools.

Focus group discussions and interviews were analysed in terms of relevant content issues that are key to better understand the triangulation of language ideologies, identities and policies. Furthermore, classroom audio-recordings were analysed by taking into account recurrent interactional moments in the course of an educational activity in a particular CLIL Science lesson. Following Heller and Martin-Jones (2001), the research uses a linguistic ethnographic lens: it pays close attention to turn-taking, participation frameworks, language choice and social categorisation with the aim of tying processes of identity construction to language ideologies (Pavlenko \& Blackledge, 2004) that circulate widely in Castilla-La 
Mancha's bilingual school communities and which contribute to legitimate (Bourdieu \& Thompson, 1991) bilingual selves.

\section{Description of sites}

San Marcos' and San Teo's belong to the state-subsidised group of schools in La Mancha City that have opted to implement one of the Linguistic Programmes on the development level. Both fulfil the two official requirements: availability of teachers with an accredited B2 level of English and providing at least two curricular subjects taught in English. Through their bilingual programmes, the institutions are currently aiming to become national reference schools: these are educational institutions which carry out successful innovative projects such as those involving bilingual programmes. In most bilingual schools in Castilla-La Mancha, the native language assistants provided by the regional administration (for state schools) and those hired by subsidised schools (as in the case of both schools under study) generally come from either the UK or the US.

\section{San Marcos'}

Built by a religious order, the school is located in a traditionally working-class neighbourhood near the city centre where new wealthy families have settled in recent decades. Lately, the school has implemented the 'Multilingual/Trilingual Programme' (Spanish-English-French), which creates a group of students in the $3^{\text {rd }}$ grade of Compulsory Secondary Education (CSE) labelled as 'trilingual'. Students in Grades 1, 2 and 4 are separated into two different groups only when attending CLIL and English language classes. This establishes two categories for each group: bilingual and non-bilingual students. It is in English language classes with the bilingual group that the native English assistant supports the English language teacher every other week by preparing and delivering different oral activities related to English/American culture. However, these assistants are not necessarily required to be trained teachers.

\section{San Teo's}

San Teo's, also a religious school, was built in 1978 on the outskirts of the city; it is now surrounded by both the traditional Roma communities and the newly arrived upper middleclass families. Regarding the BP, all students are integrated into the CLIL classroom, although parents can choose whether they want their children to follow it or not. If students are enrolled in the BP, they are required to pay extra fees to receive the privilege of being taught by a native English teacher. While the term 'native speaker' is problematic, the term will be used for the purpose of this article in the way that participants utilised it, that is, as 
encapsulating those speakers whose first language is English.

\section{Data analysis: commodification, elitism and bilingual selves}

In order to account for the appropriations of the English language that, in turn, (re)shape language ideologies and identities in La Mancha City, it is necessary to understand the role of education as a key site in the production and reproduction of social order, and school as an institutional space which manages linguistic resources and constructs what counts as 'appropriate' and 'legitimate' in terms of knowledge, language choice and participation of speakers as social agents (Heller \& Martin-Jones, 2001). Classroom interactions were transcribed following Conversation Analysis (Sacks, Jefferson, \& Schegloff, 1984) to better grasp essential interactional information. For this paper, however, the original interview transcripts have been simplified, as content is the focus of the analysis here. The following data analysis will be structured according to three main emerging issues: 1) commodification of English; 2) elitism and bilingual community membership; and 3) appropriation and bilingual selves.

\section{Commodification of English: Capital and success}

The way these institutional spaces in La Mancha City have incorporated the English language into their daily practices relies on sharing and shaping dominant ideologies of English as a profitable commodity, rather than merely a means of communication. English is seen as a useful tool to gain access to many social spheres, and to have better job opportunities in the future. This ideology is reflected in the extract below. The trilingual students in San Marcos' were asked about their opinion on the bi/trilingual programme. (See transcription conventions in Appendix.)

\section{Extract 2. San Marcos ': Focus group discussion}

(Helena (H): researcher; Ana (A): student)

$1 \mathrm{H}$ : What do you think about the bilingual programme?

2 A: It will improve our level and it will be better for our future

3 H: Why?

4 A: Because every day English and other languages are more useful in our lives and when I talk with my mother she told me I don't know English $\downarrow$ ((@@@)) and it’s if you don't know English it's bad for you.

From Ana's perspective, language learning implies personal improvement and greater opportunities to develop language skills, which in turn embeds enhanced possibilities of getting a better job. By aligning herself with the dominant ideology circulating among 
parents' discourse, Ana brings to the fore the 'good/bad' dichotomy about the presence or absence of English (line 2). Knowing English is categorised as 'good' as opposed to the negative aspect of lacking such knowledge embodied by previous generations of ashamed parents that could not learn English in the mainstream education (line 5). In this sense, it is remarkable how this student positions herself in a more privileged place than her mother was able to enjoy. The falling intonation emphasises Ana's mother's sadness and shame; this immediately evokes laughter from other students and consequently Ana's clarification about the 'sad' point of lacking knowledge of English. This echoes the discourse of not knowing English as something which is considered as 'bad'. This links to the interview with Julia, the English teacher at San Marcos', where Julia gives a sceptical view of overcoming that shame in relation to other European countries which boast a higher level of English (see extract 1 in Introduction).

In San Teo's, commodification of English takes tangible shape in the form of additional fees (39 euros/month) paid by those parents whose children receive bilingual education. Capital is not only symbolic but also material in the economic sense. Even though bilingualism is offered to all students in Castilla-La Mancha, the availability of language assistants who are native speakers of English is limited in most state bilingual schools of the region. State-subsidised centres have enough private financial support to hire their own teachers; the teachers involved in the bilingual programme who are considered 'native speakers' fulfil the language requirements. However, they do not necessarily have any CLIL or specialised-subject training (e.g. Technology, Science, Religion, or Arts and Crafts). Yet in San Teo's, these native speakers of English do function as CLIL teachers. The added value English takes in this particular school context is reinforced by the presence of the "native speaker'.

Native speakers of English is seen as an integral part of San Teo's bilingual programme. For families, the term 'native' was conceptualised as being inclusive of those Spanish teachers with a C1 level of English (CEFR). Nevertheless, in an interview, mothers claimed that they were paying for those native teachers as "an extra". Families' conceptions of the native speaker tightly connect with the Chomskyan "ideal speaker" perspective (1965), which is imbued in the image the school projects as part of their bilingual identity construction. Similarly, this institution appropriates the term 'native' in order to construct what they imagine as 'a real bilingual identity'. Nativism is therefore commodified as "extra", that is, native English teachers are constructed as objects providing goods to be consumed. 


\section{Elitism and bilingual community membership}

In these bilingual institutional spaces, appropriating English knowledge (understood not only as the language itself but the actual native English teachers embodying it) as part of the school's daily communicative practices makes the school socially acknowledged as 'better' than any other school in the local community. The co-construction of bilingual identities is therefore a cause-and-effect of the social image the schools 'sells' to the local community. In this way, ownership and membership (Pavlenko \& Norton, 2007) are two features shared by bilingual schools in Castilla-La Mancha that make them distinguishable both from each other and from other non-bilingual schools, all of them competing for prestige.

According to one of the two native English teachers in San Teo's, Sandra, the school is constructed as offering "the best bilingual classes" in La Mancha City due to the availability of native English teachers that make this school unique in the local area. This is illustrated in the following extract:

\section{Extract 3. San Teo's. Interview with the native English teacher} ((Sandra (SR))

And then other teachers say yes really good their English was really good the parents in general all the comments that I've heard from parents are really positive like it's really good you know we are really really pleased we've got the best bilingual classes in ((La Mancha City)) you know

From Sandra's position as a 'native', the construction of this school as 'proper bilingual' is reliant on how she aligns herself with teachers' and parents' discourse about having native English teachers in the bilingual programme. Sandra brings to the fore the 'nativist' ideology of the 'ideal speaker' by positioning herself as an "animator" (Goffman, 1981) of the voice of other teachers and parents for whom a native English language is regarded as the most desirable form of knowledge. In fact, she evaluates students as having a 'good' English level as a consequence of "the best bilingual classes" in secondary education: these are classes that Sandra herself teaches.

Likewise, when Claudia, the coordinator of this bilingual programme was asked about teachers' required language accreditation, she acknowledged that native teachers were the reason why the school was constructed as having "a bilingualism of excellence":

Extract 4. San Teo's. Interview with Claudia, the BP coordinator ((Claudia $(\mathrm{C}))$

Now we are forcing a bit with the $\mathrm{C} 1$ but actually our eh well we are bilingualism 
of excellence [...] but what happens our bilingualism is actually taught by the native At language policy level, and even though the constructed identity of the school as a 'top' bilingual community is linked to the native English teachers, the school did not fulfil all the requirements to implement the 'excellence' stage of implementation of the BP. In order to be officially categorised as an 'excellence' bilingual school, at least one of the specialisedsubject teachers must hold a C1 level accreditation, which was not the case in San Teo's. As a consequence, native English teachers in this school are the ones sustaining this 'imagined' bilingual community of members, boosting the prestigious and distinctive quality of their bilingual programme.

\section{Appropriation: 'bilingual selves'}

San Teo's School's elitism and authenticity are attributed to the nativist ideology of the English language contributing to the construction of valued bilingual identities. In fact, this particular institutional site as an 'imagined' bilingual community has coined the neologism: 'bilingüistas' (an English equivalent might be 'bilinguist'). This category only makes sense within this bilingual community, as it originally referred to their English native teachers but then extended its meaning to non-English native teachers with an accredited $\mathrm{C} 1$ level also involved in the BP. This social category based on native-like speakers of English therefore (re)shapes 'bilingual selves' in San Teo's. Through the appropriation and transformation of the adjective 'bilingual', teachers have created a new noun by adding the Spanish suffix 'ista' ('-ist'), which entails connotations related to professional jobs or doctrines of which one is in favour. This category that defines the identity of San Teo's as being a prestigious bilingual school presumably includes the 'good' teachers. As the BP coordinator pointed out in an interview, this school community feels "very lucky to have the bilingüistas" (interview with Claudia, BP coordinator).

In San Marcos', identity construction also functions in the intersection of social categorisations and linguistic appropriations; the process is however slightly different and so is the management of the BP. In fact, the English language assistants teach only in the English-subject lessons while supporting the English language teachers whose students belong to the bi/trilingual group. The reason for such an arrangement relies on official language policies, which prevent the segregation of students in pure bilingual/non-bilingual groups for all subjects so as to avoid creating ghettos. It is precisely this categorisation of bilingual/non-bilingual students that creates a core elitist group of pupils privileged over those 
disregarded as 'not good enough' to become a member of the bilingual elite. In the words of Ernesto, the Physics teacher in this school, this bilingual/non-bilingual dichotomy sets a clearcut distinction among students by establishing categories according to their academic and intellectual performance:

Extract 5. San Marcos'. Interview with Ernesto, the Physics teacher

Here it is definitely polarised [between bilingual and non-bilingual groups]. The bilinguals are the smartest and the others are silly, lazy... [...]. Sometimes one has the feeling that being bilingual here means belonging to the most elitist intellectual class.

Ernesto's critical voice is representative of the dominant ideology among the school community regarding what 'being bilingual' entails for stakeholders. Bilingual identities seem to be socially co-constructed under the grounds of social categories of what counts as 'appropriate' bilingual selves, thus appropriating the term 'bilingual' with significant connotations to actually label those students intellectually outstanding (lines 2-3). In real classroom practices, San Marcos' bilingual students are categorised and evaluated by CLIL teachers according to 'appropriate' or 'inappropriate' participation. These two categories can be inferred from the language choice and use in the course of an interaction between the teacher and the students, as well as what the teacher considers as "good" or "bad" learners depending on whether they comply with the school's expectations about those students following the bilingual curriculum (i.e. "good" bilingual students are constructed as highlyskilled, well-behaved and successful, whereas non-bilingual ones are deemed as lazy, poorlyskilled and rather badly-behaved). In this sense, interactional patterns are key to better analyse the co-construction and reproduction of those social categories and how they affect participants' identity in the classroom.

In the following extract, Juan, the Science teacher in the first grade of CSE corrects some exercises on a photocopy by nominating students. In the process of this interactional sequence, turn-taking, positioning of both teachers and students, and language choice are central to grasp how these 'bilingual selves' are co-constructed or contested:

Extract 6. San Marcos. Science class, $1^{\text {st }}$ grade of CSE

((Juan (J), Science teacher; Daniel (D), Luisa (L), Students (Ss)))

$1 \mathrm{~J}: \quad \mathrm{Ok}($.$) do you agree? all of you?$

2 Ss: Yes

3 Ss: yes

$4 \quad(2.0)$

5 D: Eh (0.5) stems

$6 \quad$ (4.0) 
7 J: Vamos (.) que no lo has hecho

Come on (.) you haven't done it

$8 \quad(1.0)$

9 D: No ((laughter))

$10 \quad(3.0)$

$11 \mathrm{~J}$ : Continue please

$12 \quad(1.0)$

13 D: These (.) eh these are the main reproductive organs

$14 \mathrm{~J}$ : Stamens (.) these are the main reproductive organs (.) ok

15 D: Sepals (.) eh colloc (.) collectively

$16 \mathrm{~J}$ : Collectively

17 D: collectively these are called the

$18 \mathrm{~J}$ : A bit more English accent please

$19 \quad(3.0)$

$20 \mathrm{~J}: \quad$ And style?

$21 \quad(1.0)$

22 D: Eh style (.) (xxx) the (.) pistils [to the pistils]

23 J: [to the pistils] ok (4.0) good (.) eh Luisa Ramírez

$24 \quad(1.0)$

25 L: Es que el otro día los escribí (.) y los he metido esta mañana (.) y es que the other day I wrote them down (.) and I took them this morning (.) and it

26 J: han desaparecido= they have disappeared $=$

27 L: = No pero es que creo que las metí en algún libro o algo y no sé dónde las he dejado

= No but I think I put them into a book or something and I don't know where I left them

$28 \mathrm{~J}$ : de verdad (.) eso se llama organización seriously (.) that is organisation

29 L: Ya yeah

30 J: Ya Yeah

$31 \quad$ ((background noise))

32 J: No sabéis ni en qué día vivís hijos míos (6.0) can you read it (.) in another paper (.) please?

You don't know what day it is today, my dear boys (6.0) can you read it (.) in another paper (.) please?

In this extract, Daniel's and Luisa's participation is deemed 'non-appropriate' according to the school's ideological standpoint of what belonging to the bilingual group implies (i.e., clever, hard-working, highly-skilled students). It can be noted how Juan negates Daniel's inappropriate response by switching to Spanish to emphasise he has not done his required homework (lines 7-9). After demanding that Daniel (back to the English language) continue correcting the exercise, Juan's turn in line 19 evaluates negatively Daniel's English accent when reading the exercise aloud; this categorises him as not fulfilling the standards required 
for the students to belong to the BP. Juan's critical intervention silences Daniel, who is asked by Juan again after a few seconds. As Daniel's response is deemed 'appropriate', Juan evaluates it as "good" and starts a new turn by nominating another student, Luisa (lines 2124). Unlike Daniel, Luisa intervenes in Spanish for excusing herself for not having these exercises (line 26), which leads to the subsequent negotiation turns in Spanish by Juan and Luisa until the end of this sequence. The teacher interrupts her with a sarcastic utterance ("han desaparecido" / "they have disappeared"), thus demonstrating his disappointment (line 27), which is immediately followed by Luisa's excuse again trying to convince her teacher whose turn overlaps and, once again, interrupts her explanation (lines 28-32). After this teacher-student exchange in Spanish, Juan switches to English and turns back to the main task by politely asking Luisa to read the exercise from one of her classmates' photocopies so that they can continue with the activity.

From this sequence of action, it is significant how this teacher shapes students' performance as bilingual speakers by drawing on what he considers as a 'good' or 'appropriate' English accent, particularly taking into account that he has an accredited B2 level of English. According to what he explained in an interview, he truly believes that "it is good to be forced to learn English" as "the future is going to be like this, even though we don't like it". Thus Juan, a (non-English native) CLIL teacher, positions students as 'good' or 'bad' bilingual learners through their interactional categorisation as 'appropriate' or 'inappropriate' participants. This social categorisation influences identity construction and determines whether these students deserve to belong to the bilingual school community.

\section{Conclusion}

This article has shed light on some of the ideological dimensions of the concept of bilingualism in Castilla-La Mancha. The conceptualisation of this term has proven to be rather controversial in terms of what stakeholders understand by "being/becoming bilingual". This co-construction of the concepts of bilingualism and being/becoming bilingual seems to be tightly related to the LiEP enacted by the institutional sites of this study, as each single school manages the institutional demands on bilingual education in their own terms depending on the school's resources.

The analysis of interactional and interview data has revealed how ideologies are coconstructed in discourse and legitimated in situated classroom practices for specific social, economic and political purposes in the intersection of wider social, economic and political 
processes of globalisation and neoliberalism.

In relation to the dominant language ideologies in Castilla-La Mancha, this article has provided insights into the commodification of English as a useful tool to compete in the job market, as well as on the construction of "bilingual selves" through the appropriation of the English language and native teachers as an emblem of elitism within an "imagined" bilingual school community. Similarly, stakeholders' identities are legitimised through social categorisations of 'good/bad' and 'appropriate/inappropriate' labels regarding three different aspects: 1) bilingualism as 'excellence'; 2) bilingual students as 'brilliant'; 2) 'bilingüistas' as teaching 'the best' bilingual classes. Labelling and categorising participants in those terms has led not only to the establishment of elitist school communities, but also inequalities between bilingual/non-bilingual (excellent/worse) schools and students who cannot benefit from specific linguistic resources. The "bilingüistas" or the CLIL teachers are assigned the best group of students, as those following the bilingual curriculum tend to be considered as excellent pupils in terms of academic performance. Therefore, some tensions and dilemmas seem to exist regarding the management of bilingual education in Castilla-La Mancha; this leads to complexities in the social order of these schools striving to become bilingual.

\section{References}

Anderson, B. (Rev Ed) (1991). Imagined communities. Reflections on the origin and spread of nationalism. London: Verso.

Barcelona European Council. (2002). Multilingualism. European Commission. Retrieved from: http://ec.europa.eu/education/policy/multilingualism en Accessed 03-12-2016.

Bourdieu, P. (1991). Language and symbolic power. (J. B. Thompson, Ed.) Cambridge: Harvard University Press.

Bourdieu, P. (1985). The market of symbolic goods. Poetics, 14(1-2), 13-44.

British Council (2016). Bilingual Education in Spain. British Council. Retrieved from: https:/www.britishcouncil.es/en/partnerships/success-stories/bilingual Accessed 0112-2016.

Chomsky, N. (1965). Aspects of the theory of syntax. Cambridge, MA: Massachusetts Institute of Technology Press.

Copland, F., \& Creese, A. (2015). Linguistic ethnography: Collecting, analysing and presenting data. London: Sage

Coyle, D., Hood, P., \& Marsh, D. (2010). Content and language integrated learning. Hamburg: Ernst Klett Sprachen.

de Zarobe, Y. R., \& Lasagabaster, D. (Eds.). (2010). CLIL in Spain: Implementation, results and teacher training. Newcastle: Cambridge Scholars Publishing.

Duchêne, A., \& Heller, M. (2012). Language in late capitalism: Pride and profit (Vol. 1). A. Duchêne \& M. Heller (Eds.) Language in late capitalism: Pride and profit (pp. 4-7). New York: Routledge.

Fairclough, N. (2002). Language in new capitalism. Discourse \& Society, 13(2), 163-166. Gálvez, C. M. (2000). La enseñanza de las lenguas extranjeras en España. Ministerio de 
Educación: Spain

Goffman, E. (1981). Forms of talk. Philadelphia: University of Pennsylvania Press.

Heller, M. (2006). Linguistic minorities and modernity: A sociolinguistic ethnography.

London: Continuum.

Heller, M. (2007). Bilingualism as ideology and practice. In M. Heller (Ed.) Bilingualism: A social approach (pp. 1-22). Palgrave Macmillan UK.

Heller, M., \& Martin-Jones, M. (Eds.). (2001). Voices of authority: education and linguistic difference. Westport, Conn; London: Ablex Publishing

Holborow, M. (2007). Language, ideology and neoliberalism. Journal of Language and Politics, 6(1), 51-73.

Lin, A., Wang, W., Akamatsu, N., \& Riazi, A. M. (2002). Appropriating English, expanding identities, and re-visioning the field: From TESOL to teaching English for glocalized communication (TEGCOM). Journal of Language, Identity, and Education, 1(4), 295-316.

MECD/British Council Agreement. MECD. Programa Bilingüe MECD/British Council.

Available at: http://www.mecd.gob.es/educacion-mecd/mc/bilinguismo/convenio-mecdbc.html Accessed 06-04-2017

Lin, A., Wang, W., Akamatsu, N., \& Riazi, A. M. (2002). Appropriating English, expanding

identities, and re-visioning the field: From TESOL to teaching English for glocalized communication (TEGCOM). Journal of Language, Identity, and Education, 1(4), 295316.

Park, J. S. Y. (2011). The promise of English: Linguistic capital and the neoliberal worker in the South Korean job market. International Journal of Bilingual Education and Bilingualism, 14(4), 443-455.

Pavlenko, A. (2006). Bilingual selves. In A. Pavlenko (Ed). Bilingual education and bilingualism (pp.1-33) Clevedon, UK: Multilingual Matters

Pavlenko, A. \& Blackledge, A. (Eds) (2004). Negotiation of identities in multilingual contexts. Clevedon, UK: Multilingual Matters.

Pavlenko, A., \& Norton, B. (2007). Imagined communities, identity, and English language learning. In International handbook of English language teaching (pp. 669-680). New York: Springer US.

Sacks, H., Schegloff, E. A., \& Jefferson, G. (1974). A simplest systematics for the organization of turn-taking for conversation. Language, 50(4), 696-735.

Seidlhofer, B. (2005). English as a lingua franca. ELT journal, 59 (4), 339.

\section{Appendix}

Transcript conventions (adapted from Sacks, Schegloff \& Jefferson, 1974)

@@@ indicates laughter

(.) time elapsed in tenths of seconds

[word]

$(())$

(words)

word= word

micropause

overlapping speech

nonverbal behaviour, transcriber note

non-audible segment, uncertain

no interval between adjacent utterance

\footnotetext{
${ }^{1}$ Names of participants and places have been anonymised throughout this paper.
} 
Author's information:

Alicia Fernández Barrera is a Research Fellow and $\mathrm{PhD}$ student at the University of Castilla-La Mancha (UCLM), Spain. Her research focuses on bilingualism, language ideologies and policies in educational CLIL contexts. Alicia was awarded a Doctoral Research Fellowship by the Spanish Ministry of Education, Culture and Sport (2015-2019).

Email: Alicia.fbarrera@uclm.es

To cite this article:

Fernández Barrera, A. (2017). Language appropriations, ideologies and identities in bilingual schools in CastillaLa Mancha (Spain). Bellaterra Journal of Teaching \& Learning Language \& Literature, 10(2), 41-58. DOI: http://dx.doi.org/10.5565/rev/jt13.731 